\title{
Reflections on the validity of exculpatory clauses in light of Section 6:152 of the Hungarian Civil Code
}

\begin{abstract}
Section 6:152 of the Hungarian Civil Code (HCC) is an objective cap on the freedom of contract, it is an unconditional (absolute) and minimum protection to which all exculpatory clauses are subject. In this essay, this rule is examined in a wide and complex context. These exculpatory clauses are closely connected to the consent of an injured person or their assumption of risk, or their waiver (especially waiving claims for damages) as unilateral juridical acts. The relationship between this statute and other grounds of invalidity shall also be examined, especially the connection to the invalidity rule of unfair standard contract terms.
\end{abstract}

Keywords: clause limiting or excluding liability, consent to damage, general contract terms, unfair contract terms, consumer protection, Hungarian Civil Code

\begin{abstract}
ABSZTRAKT
A magyar Ptk. 6:152. szakasza a felelösségkizáró és korlátozó kikötések érvénytelenségének általános, a szerződési szabadság határát kijelölő abszolút jellegủ minimumszabálya. Jelen tanulmányban e szabály összetett vizsgálatára törekszünk. Szükséges ugyanis a károkozás jogellenességét kizáró károsulti beleegyezés, a kockázat tudatos vállalása illetve a joglemondás (itt elsősorban a szerződésszegésből fakadó igények érvényesítéséröl való lemondás) mint jognyilatkozat elemzése is. Ugyanígy vizsgáljuk e tilalom más érvénytelenségi okokkal való viszonyát, elsősorban a tisztességtelen általános szerződési feltételek tényállását.
\end{abstract}

Kulcsszavak: felelősségkizáró illetve korlátozó kikötések, károsulti beleegyezés, általános szerződési feltételek, tisztességtelen szerződési feltételek, fogyasztóvédelem, Polgári Törvénykönyv

The general rule of nullity is formulated by Section 6:152 of the Hungarian Civil Code $(\mathrm{HCC})$ against certain limitative or exonerative contract terms (hereinafter also referred to as exculpatory clauses) and it is to be applied to all types of contracts, for all types of breach of contract, and for all types of remedies. Furthermore, this statute is free from special conditions, and applying this rule, the validity of a given term is to be examined - theoretically - independently from other terms of the contract. This rule is an objective cap of the freedom of contract, it is an unconditional (absolute) and minimum protection to which all exculpatory clauses are subject: "Contract clauses limiting or excluding liability for breach of contract intentionally, as well as for the breach of contract harming human life, physical integrity and health shall be null and void."

* Dr. Réka Pusztahelyi, Associate professor, University of Miskolc (Hungary) Faculty of Law, Institute of Private Law, jogreka@uni-miskolc.hu, reka.pusztahelyi@gmail.com. The project no. K124797 has been implemented with the support provided from the National Research, Development and Innovation Fund of Hungary, financed under the K17 funding scheme. 
This limit imposed by law is based on several rationales, as stated by Eörsi. ${ }^{1}$ According to one of these approaches, to the risk-allocating approach, every enterprise has to bear its own costs, including the damage caused. Since they are the best loss distributors among the market participants either by distributing the loss among their customers with internalising these costs into market prices or distributing the loss among the group of market participants causing similar damage, i.e. by passing the risk to insurance companies and within risk-allocating groups of enterprises being similar potential tortfeasors. However, the risk-allocating function of legal rules relating to liability for damages and the risk allocating function of the contract could lead to different results. Therefore, the enterprises cannot exonerate themselves from certain kinds of damage, especially caused by intentional conduct. The other approach is focusing on the interest of injured persons, and it establishes a minimum and undiminishable protection of certain values like life, bodily and mental integrity etc. It should also be mentioned here that other general principles can also limit the freedom of contract. The prohibition of abusive exercise of rights is the rule to which the principle of freedom of contract is subjected, as well, especially when the abuse of rights materializes in the abuse of the negotiating power of the contracting party. ${ }^{2}$

In this essay, the above-mentioned legal provision of HCC is examined in a wide and complex context. Since these exculpatory clauses are closely connected to the consent of the injured person or their assumption of risk, or their waiver (especially waiving claims for damages) as unilateral juridical acts. The relation between this statute and other grounds of invalidity should also be examined, especially the connection to the invalidity rule of unfair standard contract terms.

This complex examination of this single provision is based on the consideration that the other provisions, i.e., the ones referring to contractual liability for damages and to remedies for breach of contract, which directly affect the application of this general invalidity rule of exculpatory clauses, have been changed significantly in the new Hungarian Civil Code. It should be added that this work does not aim to address all the issues concerning special types of contracts or special risks (e.g. travel contracts, construction contracts). It remains on an abstract level where the comparative analysis method is applied to reveal the principles and policies underlying this general limit of the freedom of contract.

\section{Freedom of contract and limitative clauses of liability for breach of contract in the old and the new HCC}

The principle of private autonomy is based on three pillars: the absolute recognition and protection of private ownership, the acceptance of contractual freedom, and the freedom of association and the establishment of a legal person. ${ }^{3}$ Under Section

${ }^{1}$ Eörsi, Gyula: The Validity of Clauses Excluding or Limiting Liability. The American Journal of Comparative Law, 1975/2, 215. (doi: 10.2307/839105).

${ }^{2}$ Leszkoven, László: Szerződésszegés a polgári jogban. Wolters Kluwer, Budapest, 2016, 120.

${ }^{3}$ Vékás, Lajos: Szerződési jog, Általános rész. ELTE, Budapest, 2016, 37. 
6:59 of HCC the parties are free to determine the content of the contract. The parties may depart from the provisions relating to their rights and obligations with mutual consent, unless prohibited by the Civil Code. The freedom to establish the content of contract is limited by mandatory rules which prohibit or require certain conduct from the parties. ${ }^{4}$ One of these prohibitions is the provision of $6: 152$ of $\mathrm{HCC}$ serving as a basis for invalidity.

Although the function of this rule did not change in the new Civil Code, its regulation method and its regulatory environment has changed significantly. In contrast with the regulation of the old $\mathrm{HCC}$ of $1959,{ }^{5}$ the lawmakers had dropped the condition that the disadvantage incurred thereby should be offset by the adequate reduction of the consideration or by some other advantage. The other modification is that the new rule does not mention the gross negligence, only the intentional breach of contract. It means that the party could theoretically limit or exclude its liability for negligent conduct resulting in non-performance.

The question is whether the non-mandatory nature of contract law, that is, the freedom of contract has been extended as the cases of invalid limitative clauses has been reduced. Will the limitative clauses flourish merely because the condition of compensation has been dropped? Does it jeopardize the balance of contract? In our opinion, instead of this minimum and absolute rule, other principles, e.g. the principle of good faith and fair dealing, the prohibition of abuse of rights will be activated to protect the legal balance between parties' interests and to prevent the harmful effects due to imbalance of bargaining power. The fewer cases there will be when this provision (Section 6:152) will be applied, the more important the other grounds of invalidity will be. ${ }^{6}$

As it was mentioned above, the risk-allocating function manifests also in the provisions of HCC. ${ }^{7}$ Tibor Nochta stated that as the liability rules for breach of contract - especially the liability for damages - have been modified significantly and turned out to be basically more rigorous, so the non-mandatory nature of these rules, with the restriction of damage to the foreseeable ones may enhance the importance of the exonerative clauses concluded by the parties. ${ }^{8}$ In our opinion, the risks emerging from a contractual relationship mostly emerge from the breach of contract.

\footnotetext{
${ }^{4}$ Vékás: op.cit., 46.

${ }^{5}$ Relating to the old HCC rules, Attila Menyhárd conducted exhaustive research on regulation of limitative and exonerative clauses in the main modern law systems and in their judicature. Menyhárd, Attila: A szerződésszegésért való felelősség korlátozása és kizárása. In: Harmathy, Attila (ed.): Jogi tanulmányok. ELTE ÁJK, Budapest, 2000, 123-165. The monograph of Alexander Bruns should also be mentioned: Bruns, Alexander: Haftungsbeschränkung und Mindesthaftung. Mohr Siebeck, Tübingen, 2003.

${ }^{6}$ See also Draft Common Frame of Reference (DCFR) III.-3:105: Term excluding or restricting remedies, Section 2. A term excluding or restricting a remedy for non-performance of an obligation, even if valid and otherwise effective, having regard in particular to the rules on unfair contract terms in Book II, Chapter 9, Section 4, may nevertheless not be invoked if it would be contrary to good faith and fair dealing to do so.

${ }^{7}$ Nochta, Tibor-Papp, Tekla: Üzleti kockázat a szerződéses viszonyokban. Menedzser Praxis, Budapest, 2019, 74.

${ }^{8}$ Mónika Csöndes shares the same view about the "career" of the new provision. See Csöndes, Mónika: Elörelátható károk? ELTE Eötvös, Budapest, 2016, 184.
} 
The main factors which drive the contracting party to apply limitative clauses are the strict liability and the significant risk of damage. In contrast with the old HCC, the new HCC introduced the reduction of indemnification of consequential damage to the foreseeable ones. ${ }^{9}$ This amendment will also have an effect upon the application and wording of limitative clauses in the practice.

The exculpatory clause does not only grant for the party the possibility of exoneration (in part or in whole) from the liability. In default of this kind of clauses, the party must prove that the breach of contract was caused by a circumstance that was beyond their control and was unforeseeable at the time of concluding the contract, and they could not be expected to have avoided that circumstance or averted the damage. ${ }^{10} \mathrm{An}$ "exculpatory clause" has an intrinsic function to remove this burden of proof e.g. in case of damage caused by force majeure (vis major). ${ }^{11}$

\section{Rules of invalidity concerning limitative or exonerative clauses in HCC}

In the following, two statutes of HCC will be compared, Section 6:152 and Section 6:526.

Under Section 6:152 (Limitation and exclusion of the legal consequences of breach of contract) contract clauses limiting or excluding liability for damage caused by breach of contract intentionally, as well as for the breach of contract harming human life, physical integrity and health shall be null and void.

Pursuant to Section 6:526 (Limitation and exclusion of liability for causing damage) contract clauses limiting or excluding liability for intentionally causing damage, as well as for harming human life, physical integrity and health shall be null and void.

Between the two section titles there is a significant difference. The first provision concerns all legal consequences (i.e. remedies) of a breach of contract, the latter only concerns causing damage.

Since the claim for specific performance (performance in kind) can be inverted to claim for damages in part or in whole, a limitative clause often materializes as an exemption not from all legal consequences, but mainly from the liability for damages. ${ }^{12}$ From this viewpoint, Sections 6:152 and 6:526 are "twin rules" in both regime of contractual and non-contractual liability law. It should be also added that this invalidity

\footnotetext{
${ }^{9}$ HCC Section 6:143 Subsection 2 "Other damage to the assets of the obligee and the loss of profit that occurred as a consequence of the breach of contract shall be compensated for to the extent the obligee proves that the damage, as a possible consequence of the breach of contract, was foreseeable at the time of concluding the contract."

${ }^{10}$ HCC Section 6:142 "The said party shall be relieved of liability if able to prove that the damage occurred in consequence of unforeseen circumstances beyond his control, and there had been no reasonable cause to take action for preventing or mitigating the damage."

11 "The contractor does not guarantee and does not assume any liability for any ceiling leak caused by unpredictable summer rains." See decision 44/1993 of the Hungarian Supreme Court (now Curia). See also Terré, Francois-Simler, Philippe-Lequette, Yves: Droit civil: Les obligations. Dalloz, Paris, 2005, 606.

12 Szászy, István: A kötelmi jog általános tanai. Grill, Budapest, 1943, 88.
} 
rule of the exculpatory clauses is applicable for the grievance award (compensation of pain and suffering, i.e. sérelemdíj), as well. ${ }^{13}$

Albeit, the wording of these two provisions is very similar, and their functioning seems to us to be the same, the regulation methods of the two liability regimes differ from each other significantly. As it was mentioned above, the contract rules in HCC are mainly non-mandatory rules in order to protect the freedom of contract. On the contrary, the rules of non-contractual liability are mainly mandatory rules, even if the aggrieved parties could modify the obligations of the tortfeasor or could enter a settlement. It is possible for them to rearrange the indemnification of damage in advance, e.g. by concluding liquidated damages. The validity of this agreement is determined by the provision 6:526.

Beside the general rule, private autonomy is restricted more in the cases of strict liability (the liability for highly dangerous activity and the product liability). In the frame of liability for highly dangerous activity, under Section 6:535 Subsection 3 the exclusion or limitation of liability shall be null and void; however, this prohibition shall not apply to damage caused to things. In our opinion, the starting point of this provision is not the admissibility of exonerative or limitative contract clauses, but the risk-allocation as public policy which imposes an obligation of indemnification of damage against the operator of an ultrahazardous activity. For the clauses limiting or excluding liability for damage caused to a thing, the general rule of 6:526 is to be applied, according to the principle lex specialis derogat legi generali. ${ }^{14}$

Here, it should be mentioned that a new provision of HCC, Section $6: 145$, the socalled rule of non-cumul separates the contractual and the non-contractual liability regime from each other. ${ }^{15}$ If there is a contractual relationship between the injured person and the tortfeasor, neither Section 6:525 nor Section 6:535 may be applied. Therefore, the above-mentioned public policy for risk allocating function of strict liability rule becomes irrelevant.

In the frame of product liability, limitation or exclusion of liability for damage is forbidden in any case,${ }^{16}$ so the rule of non-cumul generates even greater problems.

\section{Formulation and identification of limitative or exonerative clauses}

In practice, the exculpatory clauses may appear in the form of a contract term, or unilateral juridical act, or standard contract term, or in internal rules of an undertak-

${ }^{13}$ See Section 2:52 of HCC.

${ }^{14}$ Solt, Kornél: Kogencia és diszpozitivitás a veszélyes üzemi kártérítési felelösség körében. Jogtudományi Közlöny, 1968/6, 302-307, 304.

${ }^{15}$ The obligee may also enforce his claim for damages against the obligor in accordance with the rules on liability for damage caused by breach of contract, even if the damage gives rise to the obligor's extra-contractual liability. See Pusztahelyi, Réka: Igényhalmazatok a szerződésszegési jogkövetkezmények rendszerében, különös tekintettel a Ptk. 6:145. §-ára. Pro Futuro, 2016/2, 60-78. (doi: 10.26521/Profuturo/2016/2/5132).

${ }^{16}$ HCC Section 6:557 "Any limitation and exclusion of the producer's liability towards the injured party shall be null and void." 
ing,$^{17}$ and they generally concern only the liability for damages caused by breach of contract and not for all remedies of non-performance.

The HCC's focus is on contractual juridical acts, e.g. terms which require the consent of the other contracting party. No one could create obligational duties - as a rule - to oblige others by their juridical acts. Despite this, exculpatory clauses may appear in unilateral acts in practice, so it ought to be considered that the relevant disposition of the Draft Common Frame of Reference (DCFR) opens its scope: "A term of a contract or other juridical act which purports to exclude or restrict liability to pay damages for personal injury (including fatal injury) caused intentionally or by gross negligence is void." 18

The wording of the new Romanian Civil Code shows us the right function of limitative unilateral juridical acts. A notice which excludes or limits contractual liability, whether made public or not, has no effect unless the person who invokes it proves that the injured person was aware of the notice at the time when the contract was made. ${ }^{19}$ In our opinion, the unilateral juridical act shall not be deemed as a contractual agreement, therefore, the person who applied this notice cannot exonerate himself from liability or cannot reduce it.

The exculpatory unilateral act has no effect, but this notice makes the other party aware of the high risk of the activity and creates a link between the duty of information and the assumption of risk. On the other hand, as was mentioned before, the consent of the contracting party to bear the risk should be articulated in an express form. Moreover, the Romanian Civil Code made a further clarification: "The express acceptance of the risk of damage cannot by itself constitute a waiver of the victim's right to obtain compensation." 20

As we mentioned before the exculpatory clause concerns all type of remedies of non-performance. Its purpose could be to exclude certain claims (e.g. claim for repair or replacement on the ground of warranty for material defects), to limit the extent of claim for damages or to create an absolute stipulated sum of liquidated damages. ${ }^{21}$ The limitation of liability may concern certain types of damage (e.g. "no responsibility for discoloration or damage to abandoned buttons due to dry cleaning"). Other terms have also an implied effect to limit liability e.g. by making enforcement of claims difficult or impossible, by imposing additional conditions for claim enforcement, by reversing the burden of proof, by shortening the period of prescription or by adding a time limit to enforcing remedies (i.e. right to terminate the contract). ${ }^{22}$ In exceptional

\footnotetext{
17 Solt: op. cit.

${ }^{18}$ DCFR III.-3:105: Term excluding or restricting remedies.

${ }^{19}$ Article 1356 of the Romanian Civil Code. See Alunaru, Christian-Bojin, Lucian: Extracts from the New Romanian Civil Code. Journal of European Tort Law, 2011/1, 107-120. (doi: 10.1515/jetl.2011.107).

${ }^{20}$ Art. 1355 Section 4 of the Romanian Civil Code.

${ }^{21}$ "In some Member countries the courts will treat a penalty or liquidated damages clause as a clause limiting liability if the stipulated sum is below the damages which the creditor could recover." See Von Bar, ChristianClive, Eric-Schulte-Nölke, Hans (eds.): Principles, Definitions and Model Rules of European Private Law. Draft Common Frame of Reference (DCFR). Sellier de Gruyter, Munich, 2009. [hereinafter: DCFR Commentary] 826. (doi: 10.1515/9783866537279).

${ }^{22}$ The exercise of the right to terminate the contract as remedy was time-barred of 60 days. See Decision BDT2008.1721 of the Budapest-Capital Regional Court of Appeal.
} 
cases, the limitative clause has an effect upon third parties (e.g. excluding the right of the surety for defence of unexhausted remedies ${ }^{23}$ ).

The term of the contract is not only applied just to exclude or limit the liability, but to increase it. If a concluded clause imposes extra obligations on the party while leaving untouched the liability of the other party for breach of contract, this clause has no limitative nature, so that it is not to be assessed by the invalidity rule. ${ }^{24}$

In the light of the current Hungarian judicial practice, the question also emerges whether there is a so-called fundamental breach of contract for which the liability could not excluded or limited. Attila Menyhárd pointed out that the exculpatory clauses relating to fundamental breach of contract deprive the contractual obligation from its inherent substance, thus, this kind of clauses has no effect both in the field of common law and both in German law (i.e. Kardinalpflichten). ${ }^{25}$ In Hungarian judicial practice, a decision serves as an example stating that the liability for impossibility of performance may not be excluded by a contractual term, even if its reason cannot be attributed to either of the parties. ${ }^{26}$

Albeit, it is not worth wording this rule among the invalidity rules relating to contract terms in the Civil Code, the principle of good faith gains here a special purpose to protect the binding force of the contractual obligation. According to László Leszkoven these exculpatory clauses should be regarded as being not written (have no effect), since they violate the general principle, even if they are not expressly invalid. ${ }^{27}$ The French judicial practice had arrived at the similar conclusion relating to exculpatory clauses contrary to obligations undertaken. ${ }^{28}$ These issues show the significance of the provision of DCFR which deals with the exculpatory contract terms against good faith and fair dealing despite the act that in most cases (not in all cases however) these terms are also subject to the invalidity of unfair standard terms. ${ }^{29}$

Attila Menyhárd ${ }^{30}$ and Ádám Fuglinszky ${ }^{31}$ pointed out that in practice, instead of expressly limitative clauses, the contracting parties conclude such contractual terms which define what performance is complied with the contractual obligations, and which defects in the service of performance are not considered as a breach of contract. For example, the parties decided that the hairline fractures on the attic wall due to thermal expansion was an error which could not be considered as a breach of contract. ${ }^{32}$

The so-called definitive clause determines in detail what the parties' duties and rights are, and what is considered as non-performance. The exculpatory clause ex-

\footnotetext{
${ }^{23}$ BDT2014.3135.

${ }^{24}$ BDT2011.2556. The tenant had to take out an insurance policy for the movable property and furniture brought into the premises, but this property insurance did not dispelled the landlord's liability for water damage.

${ }^{25}$ Menyhárd (2000): op. cit., 126-127.

${ }^{26}$ Decision EBD2013.G.9. of the Szeged Regional Court of Appeal.

${ }^{27}$ Leszkoven: op. cit., 121.

28 Terré-Simler-Lequette: op. cit., 604.

${ }^{29}$ See also DCFR III.-3:105: Term excluding or restricting remedies, Section 2.

30 Menyhárd (2000): op. cit., 153-154.

${ }^{31}$ Fuglinszky, Ádám: Kártérítési jog. HVG-ORAC, Budapest, 2015, 79. (doi: 10.1628/003372515X14176993262158).

32 BH1990.343.
} 
empts the party from remedies of non-performance. Therefore, it is hard to differentiate between them, since the purpose is common: to limit the obligational duties of the contracting party. It is not the liability but the legal duty that will be in focus, thus the liability of the contracting party will be eliminated at an antecedent logical step, ${ }^{33}$ and liability cannot stem from breach of no legal duty.

According to Menyhárd the distinction can be made only on a formal level. ${ }^{34}$ In his opinion, merely classifying definitive terms as exculpatory clauses per se and applying this invalidity rule to them is a method which raises concern, because the invalidity rule might cover such cases where the restriction of freedom of contract is unnecessary. He pointed out that the judicature of Switzerland provides additional protection against these definitive clauses with the help of the principle of good faith and fair dealing, or other grounds of nullity (e.g. concluding terms to circumvent the law). ${ }^{35}$

Is it either really necessary or advisable to differentiate between definitive clauses and exculpatory clauses? Menyhárd identified the problem that the formal distinction might lead to the circumvention of the provisions which constitute limits against contract terms excluding or limiting liability for a breach of contract. ${ }^{36}$

In our opinion, the invalidity rule of Section 6:152 of HCC should be quite broadly interpreted in the judicial practice to cover the so-called definitive clauses in order to protect the balance of contract, provided that the contracting party actually wanted to avert the application of this invalidity rule. This approach appears in the French Reform Bill on Civil Liability of 2017: "Contract terms whose object or effect is to exclude or to limit liability are in principle valid, in contractual as well as in extra-contractual matters. However, in the case of personal injury, liability cannot be limited or excluded by contract." ${ }^{\prime 37}$

\section{Meaning of an intentional breach of contract in light of limitative clauses}

Parallelly with the invalidity of contractual terms limiting or excluding liability for an intentional breach of contract, the damage to be paid is not limited to that which is foreseeable provided that the breach of contract causing that damage was intentional. ${ }^{38}$

${ }^{33}$ Fuglinszky (2015): op. cit., 79.

${ }^{34}$ Menyhárd, Attila: Fogyasztóvédelem és felelösségkorlátozás. Gazdaság és Jog, 2001/12, 22.

${ }^{35}$ Menyhárd (2000): op. cit., 129.

${ }^{36}$ Menyhárd (2001): op. cit., 22.

${ }^{37}$ Reform Bill on Civil Liability of 2017, Art. 1281 Section 1: Contract terms excluding or limiting liability (translated by Simon Whittaker). http://www.textes.justice.gouv.fr/art_pix/reform_bill_on_civil_liability_march_2017. pdf (2020. 01. 04.).

${ }^{38}$ HCC Section 6:143 Subsection 2 and 3 „Other damage to the assets of the obligee and the loss of profit that occurred as a consequence of the breach of contract shall be compensated for to the extent the obligee proves that the damage, as a possible consequence of the breach of contract, was foreseeable at the time of concluding the contract. In the event of intentional breach of contract, the entire amount of damage arising on the part of the obligee shall be compensated for." 
The next question is whether the intentionality of the conduct (intentional breach of contract) as factual elements of the statutes in 6:143 Subsection 3 and in Section $6: 152$ are the same.

In the frame of the amount of damage, the intentional breach of a contract means that the obligor was fully aware of the consequences of their conduct and acted willingly, premeditated or, acquiesced to the consequences of his conduct. The blameworthiness of his conduct (in the meaning of the generally expected standard of conduct, or fault in objective meaning) is not a condition, because they did not have the possibility to avoid the non-performance, and so it was a reasonable business decision. It is not a required condition that they intended to cause damage to the other party. ${ }^{39}$ The meaning of the intentionality of non-performance in the light of the contractual liability rules of the new Civil Code is discussed by recent Hungarian legal literature. László Leszkoven considers that the meaning of intentionality is closer to the premeditation (dolus directus) than to conditional intent (dolus eventualis). ${ }^{40}$ Ádám Fuglinszky examines in detail the adaptability of the criminal concepts of intent (dolus) and the accountability of human intentional conduct to legal persons. $\mathrm{He}$ thinks that the shades of meaning will be elaborated by the interpretation of future legal practice. ${ }^{41}$ Attila Menyhárd also mentioned that the interpretation of this subjective mental element should be very abstract. ${ }^{42}$

In the scope of limitation of liability, however, the broadened concept of intentionality seems to be more equitable, in light of the fact that not only the intentional but also grossly negligent breach of contract were subject to the former rule of invalidity in Civil Code of 1959 in the case of which the limitation or exclusion of liability by term of contract was prohibited. Moreover, it should be also taken into consideration that most European countries extended the scope of invalidity to the terms limiting or excluding liability not only for intent but also for gross negligence, as did the DCFR as well. ${ }^{43}$ The reason why the former rule had to be amended in that regard is the difficulty of distinguishing between gross and simple negligence in practice. ${ }^{44}$

\section{Concluding limitative clause or waiving a right}

The limitative terms need to be concluded, that is, should be the part of the contractual agreement. From the viewpoint of the party applying an exculpatory clause, it needs the other party's consent. With his consent, the liability was limited (or excluded), thus, he waived some of his rights stemming from non-performance. In our opinion, there is a close connection between a unilateral waiver and a limitative term

\footnotetext{
${ }^{39}$ Vékás: op. cit., 234.

${ }^{40}$ Leszkoven: op. cit., 161.

${ }^{41}$ Fuglinszky, Ádám: Az előreláthatósági klauzula értelmezésének újabb dilemmái. Gazdaság és Jog, 2019/78, 1-7.

42 Menyhárd, Attila: Az új Ptk. szerződési rendszere. Presentation held on 13 November 2019 at the Conference of Magyar Jogász Egylet on the Anniversary of the HCC.

43 See Notes attached to Article III.-3:105 in DCFR Commentary, 821-826.

44 It was pointed out by Eörsi. See Eörsi (1975): op. cit.
} 
of a contract. Moreover, an a priori waiver of a right on the part of the potentially aggrieved party to claim damages could also be interpreted as an express consent to suffer damage, or an assumption of risk..$^{45}$ In this latter case, the express consent justifies the harmful act and exonerates the tortfeasor (the party of the contract) from the liability, and leads to no breach of contract having taken place at all. Although the term of a contract limiting or excluding liability for harming life or bodily integrity is invalid, however, the consent of the party has valid effect and eliminates wrongfulness. ${ }^{46}$

It should be mentioned here that these interpretations and the exculpatory clauses relating to harming life or bodily integrity should be limited to a narrow field of special cases in order to protect these values. For example, in the judicature of the USA these exculpatory clauses are only invalid in the contracts for extreme sports, e.g. parachuting. ${ }^{47}$

Examining further the party's waiving, according to Section 6:8 Subsection 3 of $\mathrm{HCC}$ a waiver or release of a right shall be made by way of an express juridical act. If someone waives or releases a right, his juridical act shall not be interpreted broadly.

Ádám Fuglinszky added that the rules of invalidity and ineffectiveness related to the juridical acts are to be applied as well. ${ }^{48}$ In relation to consent, Fuglinszky reminds us of the cautious application of the provisions concerning exculpatory clauses: ${ }^{49}$ these rules could be applied analogously at most, since the two legal instruments (exculpatory clause and consent) do not serve the same purpose. ${ }^{50}$

According to Tamás Fézer the consent and the exculpatory clauses are closely related concepts, and he dealt with their unified application but under certain conditions. ${ }^{51}$ Another author, György Wellmann wrote the following: "In our opinion, comparing subsections 1 and 2 of section 342 the interpretation leads us to the only correct solution which is that the agreement is invalid in which the injurer excluded his liability for damages from injury and in which the injured person had given consent

45 Pusztahelyi, Réka: Assumption of Risk and Express Consent from the Viewpoint of Liability for Highly Dangerous Activities. European Integration Studies, 2017/1, 15.

${ }^{46}$ See Decision Pfv.III.20.069/2012/10 of the Curia (Hungarian Supreme Court). The Curia stated that as the injured party was aware of the high risk stemming from the use of the sport device (paraglider) the damage suffered during this activity should be borne by himself. He cannot claim for damages against the tutor. The term of the contract excluding liability of the tutor is invalid, but the Curia established the effect of the expressed consent to damage from the part of the injured party.

47 Bruns: op. cit., 80.

${ }^{48}$ Fuglinszky (2015): op. cit., 224.

${ }^{49}$ HCC Section 6:526 „Any contract term limiting or excluding liability for intentional tort or for causing damages resulting in loss of life, or harm to physical integrity or health shall be null and void." Comparing to the similar regulation of contractual exculpatory clauses, in our opinion, the English version of the latter - the contractual one - does not show the fact that there are two separated states of facts which make the agreements of that kind invalid.

${ }^{50}$ Fuglinszky, Ádám: 6.520. § In: Osztovits, András (ed): A Polgári Törvénykönyvről szóló 2013. évi V. törvény és a kapcsolódó jogszabályok nagykommentárja IV. OPTEN, Budapest, 2014, 53.

${ }^{51}$ Fézer, Tamás: A kártérítési felelősség feltételei. In: Fézer, Tamás (ed.). A kártéritési jog magyarázata. Wolters Kluwer, Budapest, 2010, 94-95. 
to be injured in his bodily integrity and to bear the consequences - provided that the agreement neither infringes nor endangers social interest or public policy." 52

Gyula Eörsi also analysed this issue: it is not unlawful to cause damage with the consent of the injured party within limits. He referred to invalidity of exculpatory clauses, and added that such a juridical act in the contract was not meant to be interpreted in each case as an express consent, but it has a similar effect in the viewpoint of the law, since it grants exoneration from liability by a legal statement..$^{53}$

Reviewing the Hungarian theoretical opinions, our conclusion is that the antecedent legal opinions sought the solution of the collision of the provisions in the bilateral nature of the agreements including the voluntary acquiescence of the injured person. The recent legal opinion stressed the differences between the express consent and the assumption of risk to resolve the discrepancy and answer the practical questions.

As the exonerative effect of express consent does not require anymore that the consent should neither infringe nor endanger social interest or public policy, it seems that an onerous condition was removed out of the way of the free interpretation. Therefore, the importance of the invalidity of the prohibited exculpatory clauses will increase on the other side of the scale.

The waiver or release of a right to claim remedies of breach of contract should be assessed separately from the juridical acts in which the contracting party waives the right of contesting on the ground of invalidity ${ }^{54}$ or waives the right to request the legal consequences of invalidity. ${ }^{55}$

The contracting party could waive their right to claim damages either before (a priori waiver, waiver in advance) or after suffering damage (a posteriori waiver, waiver afterward). In many cases, the careful examination of the express nature of the waiver reveals the issue whether the party was fully aware of the consequences of their legal statement. The a priori waiver - as a rule - is deemed as valid, the private autonomy does not suffer such a limitation. As stated by Dezsö Nagy, even rights of content or of extent yet unknown could be waived, provided that, the right should be individualised and identified so that it is undoubtful what it constitutes. ${ }^{56}$ According to some decision from the Hungarian judicial practice, the claim should already exist when the waiver has occurred otherwise its content will not be unequivocal. ${ }^{57}$ At this point, assessing the express nature of an a priori or a posteriori waiver, we can sense the working of the phenomena that Salamon Beck showed:

\footnotetext{
52 Wellmann, György: A kártérítési felelösséget korlátozó és kizáró körülmények. In: Petrik, Ferenc (ed).: A kártérítési jog. KJK, Budapest, 1991, 51.

${ }^{53}$ Eörsi, Gyula: A polgári jogi kártérítési felelősség kézikönyve. Budapest, KJK, 1966, 117-118.

54 See Section 6:89 Subsection 5 of HCC.

${ }^{55}$ HCC Section 6:90 Subsection 3 „A person who could recognise his mistake or undertook the risk of being mistaken shall not be entitled to contest the contract.”; Section 6:98 Subsection 2 „Except for contracts between consumers and undertakings, the parties may exclude in the contract the right to contest as determined in Subsection 1."

${ }^{56}$ Nagy, Dezső, ifj.: Adalékok a joglemondás tanához. Polgári Jog, 1937/2, 66.

57 BH2016.313.
} 
the binding nature is attached differently to the rules concerning different life stages of the contractual obligation (so-called "létszaki kógensség"). ${ }^{58}$

In consumer contracts the validity of waivers made by the consumer is limited further. Most of all waivers, whether made by a consumer in advance or afterwards, are invalid. This is the case as the consumer may not validly waive any special rights granted to the consumer in the special rules governing the terms of the consumer contract. $^{59}$

Another interesting issue should also be mentioned which helps us to understand the interaction between consent, assumption of risk and limitative clause or notice. One element can be found in the new Romanian Civil Code, in Section 1355. The Subsection 4 stipulates that the express acceptance of the risk of damage cannot by itself constitute a waiver of the victim's right to obtain compensation. That means not all express acceptances of risk are considered to be a waiver of rights.

On the other hand, as to the connection between limitative clauses and the consent to damage, Section 65 Subsection 2 of the Consumer Rights Act 2015 of the United Kingdom gives further clues: "Where a term of a consumer contract, or a consumer notice, purports to exclude or restrict a trader's liability for negligence, a person is not to be taken to have voluntarily accepted any risk merely because the person agreed to or knew about the term or notice." It means that the burden of proof is laid on the trader in order to prove that the conclusion of the limitative or exonerative contract term (or tacit acquiescence of a notice) is interpreted as an acceptance of the risk.

In conclusion, in light of the legal effect, the exculpatory clauses are closely connected to the consent of the contracting party to be potentially injured. In this context, a limitative term may be interpreted as a juridical act of that party waiving his rights in advance. Concluding an exonerative or limitative term means that the party releases the right to claim remedies. Taking into consideration this conceptual connection, the requirement of an express waiver seems to be applied to the limitative terms of contract, as well. Therefore, being applied time to time the same limitative term among the standard terms and conditions may become custom or practice, nevertheless, it will become part of the content of the contract provided only that the contracting parties have agreed to it expressly. ${ }^{60}$

In consumer contracts, with the rights granted by special rules for consumers, and only in the scope of those rights, waivers are invalid regardless of the content of the given juridical act. The invalidity of a waiver may also have an effect upon the

${ }^{58}$ Beck, Salamon: Létszaki cogensség. Polgári Jog, 1932/1, 24-25. The best example is the rule prohibiting lex commissoria: Under Section 5:135 of HCC any agreement allowing the pledgee to acquire the ownership of the pledged item upon when the right to satisfaction may be exercised shall be null and void.

59 HCC Section 6:101.

${ }^{60}$ HCC Section 6:63 Subsection 5 „Any custom having been agreed between the parties in their earlier business relationship and any practice having been established by them shall become a content of the contract. Any custom widely known and regularly applied by parties to contracts of similar nature in the relevant business sector shall become a content of the contract, unless its application would be unjustified considering their earlier relationship." About this problem see Csehi, Zoltán: Kártérítési felelősség megújulása az új Polgári Törvénykönyvben. Manuscript, forthcoming in Magyar Jogászegyleti Értekezések. 
validity of limitative terms. Despite the close connection between limitative terms of contracts and acceptance of risk, the thought is acceptable according to which the trader (business) has to prove the fact that the consumer accepted not only the term of contract but expressly the risk of damage.

\section{Limitative contract terms which are excessively general}

General and vague contract terms are common in practice, especially in the field of consumers contracts. These terms are worded in a very simply way, with the contracting party exonerating themselves of all risks and liability. For example: "By purchasing a ticket, the visitor irrevocably accepts these terms and conditions of the go-kart track. Liability for damages is excluded." Or: "The use of facilities, free or rentable sport equipment in the camp of $X Y$ is at the sole risk of the guests, and the owner excludes any liability for damages."

These general exonerative terms are invalid, because they exclude liability for damage not only to property but also to personal rights (life, bodily integrity). According to another interpretation, these clauses should be assessed retrospectively, in light of the suffered harm, whether the liability for the damage occurred is limited or not. ${ }^{61}$ However, the other approach, the consent given by the injured person, should be taken into consideration again, and these clauses are missing the expressed nature of the consent to suffer damage.

In the judicial practice, with the help of the appropriate interpretation of a limitative term worded vaguely, the court is able to avoid the formal nullity. The reasoning of the following decision seems to be analogously applicable, in which the lawsuit of the plaintiff was based on the nullity of unfair contract terms. The court stated that the general terms and conditions (including limitative terms) concerning bank accounts are also subjected to the relevant legal provisions which should be taken into account while interpreting the limitative clauses. The bank was not intended to infringe statutory provisions with this exculpatory clause at issue. ${ }^{62}$ However, in the case of contesting $\mathrm{B} 2 \mathrm{C}$ contracts, this reasoning is contrary to the special rule of interpretation. ${ }^{63}$

\section{Exculpatory clauses in light of unfair standard contract terms}

Eörsi has already listed other legal instruments as filters against contract terms limiting or excluding liability such as special requirements to apply standard contract terms and conditions, i.e. provisions relating to unfair standard contract terms or other errors in the intended legal effect, or, the principle of in dubio contra proferen-

\footnotetext{
${ }^{61}$ Fuglinszky (2015): op. cit., 80.

62 Decision 4.Pf.22.107/2011/3 of the Budapest-Capital Regional Court of Appeal. In B2C contracts, this interpretation is contrary to the principle in dubio contra proferentem.

${ }^{63}$ HCC Section 6:86 Subsection 3.
} 
tem. ${ }^{64}$ For the purpose of consumer protection and to counterpoise the imbalances between contracting parties, numerous rules of nullity can be identified which are connected to the general invalidity rule of limitative clauses such as contract terms infringing consumer rights (6:100), the consumer's statement of waiver $(6: 101)$ or unfair standard contract terms $(6: 102-6: 106)$. Incomprehensible or conflicting clauses are also null and void (6:107).

In the opinion of Péter Takáts, the standard terms and conditions can be classified in two categories. In the first group, there are technical and economic conditions. The other group of terms reflect the business and legal interests of the party; therefore, this includes in particular the exculpatory clauses. ${ }^{65}$ Standardization or automation through the use of general contract terms can effectively serve the management of risks in mass transactions. Therefore, the application of limitative terms as a part of the general terms and conditions is very common.

Contrary to the general invalidity rule of $6: 152$, the invalidity rule of unfair general contract terms sets limits against contractual terms in different way. The main purpose is to protect the balance of the contractual rights and duties between the parties and to protect the contractual relationship against distortions stemming from the imbalance of bargaining powers of the contracting parties. Under Section 6:102 of HCC, a standard contract term shall be unfair if it unilaterally and unreasonably, and by violating the principle of good faith and fair dealing, sets forth the rights and obligations arising from a contract to the detriment of the party contracting with the person applying that contractual term.

The protection of consumers (who are generally the weaker party) is another purpose which should be fulfilled, but at some points, the scopes of protection overlap each other. In the field of consumer protection, Council Directive 93/13/EEC ${ }^{66}$ on unfair terms in consumer contracts listed the terms as unfair whose object or effect is to exclude or limits the legal liability of a seller or supplier in the event of the death of a consumer or personal injury to the latter resulting from an act or omission of that seller or supplier.

In the light of the above-mentioned connection between an injured person's consent to damage, assumption of risk and waiver of rights, the exonerative clauses for death or personal injuries will be invalid or ineffective in all European countries, in consumer contracts, first of all, but later on generally, in all types of contracts. ${ }^{67}$

In Hungary this special bar on limitative clauses applied in consumer contracts is missing, because a more general rule, i.e. Section 6:152 which grants absolute protection against clauses excluding or limiting liability for death or personal injuries regardless of the contracting parties.

This is one of the cases where the Hungarian lawmakers had to dissolve the collisions between invalidity rules relating to limitative clauses regulating consumer

\footnotetext{
${ }^{64} \mathrm{HCC}$ Section 6:80 Subsection 2.

65 Takáts, Péter: A szabványszerződések. Akadémiai, Budapest, 1987, 14.

${ }^{66}$ Council Directive 93/13/EEC of 5 April 1993 on unfair terms in consumer contracts. OJ L 95, 21.4.1993, p. 29-34.

${ }^{67}$ Terré-Simler-Lequette: op. cit., 609.
} 
law and the general law of obligation at the same time. In our opinion, in other cases when both a general bar and a special bar on limitative clauses are applicable, the provisions may be applied altogether. For example, the Curia (Hungarian Supreme Court) articulated in its decision that the interpretation and the application of the general invalidity in Section 314 of old HCC and the special provisions on travel contracts are to be interpreted and applied in light of the Directive on unfair contract terms of consumer contracts (especially the above-mentioned rule relating to death and personal injuries). ${ }^{68}$

Other cases of unfairness also refer to the bar on limitative and exonerative clauses such as terms that exclude or restrict the undertaking's liability for the vicarious agent used by it; ${ }^{69}$ terms that exclude or restrict the consumer's options to enforce his claims at court or through other legal ways, in particular if it exclusively forces the consumer to the arbitral route without any requirement set forth by law, or unlawfully restricts the possibilities for taking evidence or imposes a burden of proof that should be borne by the other party under the applicable legal provisions; ${ }^{70}$ or terms that exclude or restrict the consumer's rights provided by the law in the event of the undertaking's breach of contract. ${ }^{71}$

We agree with Attila Menyhárd that the control of limitative and exonerative clauses and the control of unfair general contract terms are laid on different planes of thinking. In our opinion, the main characteristic feature of the invalidity rule of unfair terms is the subjective element: the unfairness. The rule of Section 6:152 is not based on such a subjective condition. As we mentioned above it is an objective and minimum limit against contractual freedom.

The parallel regulation was maintained through the UK's recent legislation. The above-mentioned Consumer Rights Act of 2015 only amended the Unfair Contract Terms Act of 1977 (UCTA). This is despite the fact that the new act intended to streamline the legislation governing unfair terms in relation to consumer contracts, which was found in two separate pieces of legislation [UCTA and Unfair Terms in Consumer Contracts Regulations (UTCCR) of 1999] removing anomalies and overlapping provisions. ${ }^{72}$

\footnotetext{
68 Decision Pfv.V.20.952/2017/8 of the Curia.

${ }^{69}$ HCC Section 6:104 Subsection 1 point $h$ ).

${ }^{70}$ HCC Section 6:104 Subsection 1 point $\left.i\right)$.

${ }^{71}$ HCC Section 6:104 Subsection 2 point $h$ ).

72 Draft Consumer Rights Bill: Government Response to Consultations on Consumer Rights. Department of Business Innovation \& Skills, 2013. https://assets.publishing.service.gov.uk/government/uploads/system/ uploads/attachment_data/file/225989/13-916-draft-consumer-rights-bill-governemnt-response-to-consultationson-consumer-rights.pdf (04. 01. 2020.). See Gyuris, Árpád: Az Európai Unió hatása a magyar szerződési jogra (különös tekintettel a fogyasztói szerződés tisztességtelen feltételei szabályainak meghatározására a magyar magánjogi kódexekben). Doctoral dissertation, Pázmány Péter Catholic University (Budapest, Hungary), 2018, 326. (doi: 10.15774/PPKE.JAK.2018.003).
} 


\section{Final remarks}

Among the rules setting up controls of contractual terms limiting or excluding liability, the invalidity rule in section 6:152 of $\mathrm{HCC}$ constitutes the most general bar. As mentioned above, it is an objective cap of the freedom of contract, an unconditional (absolute) and minimum protection to which all exculpatory clauses are subject. Compared to other grounds of invalidity, it constitutes a bar being without a subjective element, that is to say, irrespective of the nature of the particular contract type, the quality of the contracting parties, or other terms of the contract. On the one hand, the new Hungarian Civil Code restricted its scope of application to the narrowest possible field to protect the principle of freedom of contract. On the other hand, based on the general nature of the prohibition, it maintained this rule despite the fact that it has a wide application scope similarly to the invalidity rules relating to unfair standard terms.

In this essay, the interactions between limitative clauses and the consent to damage, the assumption of risk, and the waiver of a right were also examined, since in the judicial practice the consent of an injured person (rarely) has legal effect and exempts the tortfeasor from liability, although the invalidity of terms excluding liability for personal injuries is undoubtedly invalid. The influence of consumer protection suggests that this narrow exception should be outlined better. Neither the general prohibition of, nor the total freedom of terms excluding or limiting liability for death or personal injuries is a better solution. However, in an extreme situation such as parachuting, it is unreasonable to protect the contracting party as consumer (volunti non fit iniura).

Our conclusion is that the express nature of the consent should also be required for the exculpatory clauses.

In the regime of delictual liability the invalidity rule of limitative clauses is repeated, not only as a general rule, but also in special, more stringent invalidity rules attached to cases of strict liability. The so-called "non-cumul" rule, laid down in Section 6:145 of HCC would threaten that this stricter bar on limitative clauses may not be applied if there is a contractual relationship between parties. 